\title{
Adipose-Derived Mesenchymal Stem Cells for Treatment Tertiary Failure Diabetes Mellitus Type 2
}

\author{
Purwati $^{1,2}$, Sony Wibisono ${ }^{3}$, Ari Sutjahjo ${ }^{3}$, Askandar T.J ${ }^{3}$, Fedik A.R ${ }^{1}$ \\ ${ }^{1}$. Stem Cell Research and Development Centre, Universitas Airlangga, Surabaya, Indonesia \\ 2. Cell and Tissue Bank, Dr. Soetomo General Hospital, Surabaya, Indonesia \\ ${ }^{3 .}$ Endocrine Division Department of Internal Medicine, Faculty of Medicine, Universitas Airlangga, Surabaya, \\ Indonesia \\ purwatipanpan@yahoo.com
}

\begin{abstract}
Recent progress in diabetes mellitus therapy has focused attention on generation of surrogate $\beta$-cells from mesenchymal stem cells (MSCs) derived adult tissues. In this study, we conducted a phase I clinical trial in patients with type 2 diabetes mellitus in various age between 30-79 years old who were treated with autologous adiposederived MSCs transplantation. MSCs injected into diabetic patients through catheterization then we measured levels of fasting blood glucose, $2 \mathrm{~h}$ postprandial blood glucose, insulin, c-peptide pre and post stem cell transplantation, also $\mathrm{HbA} 1 \mathrm{c}$. Levels of blood glucose (fasting and $2 \mathrm{~h}$ post prandial) and insulin were absolutely decreasing after injection. Meanwhile, level of c-peptide was increasing after injection. Level of HbAlc was significantly decreasing after 3 months injection. Thus, adipose-derived mesenchymal stem cells for treatment tertiary failure diabetes mellitus type 2 was better than insulin treatment only.

[Purwati, Sony Wibisono, Ari Sutjahjo, Askandar T.J, Fedik A.R. Adipose-Derived Mesenchymal Stem Cells for Treatment Tertiary Failure Diabetes Mellitus Type 2. Stem Cell 2016;7(4):21-24]. ISSN: 1945-4570 (print); ISSN: 1945-4732 (online). http://www.sciencepub.net/stem. 4. doi:10.7537/marsscj070416.04.
\end{abstract}

Keywords: diabetes mellitus type 2, adipose tissue, mesenchymal stem cells, autologous

\section{Introduction}

Diabetes mellitus (DM) which is characterized by hyperglycemia is a group of metabolic diseases associated with dysfunction, failure of different organs, and long-term damage resulting from defects in insulin action, insulin secretion, or both (American Diabetes Association, 2012). According to International Diabetes Federation (IDF), prevalence of diabetes mellitus in 2013 is 382 million where the proportion of type 2 is $95 \%$ with undiagnosed category is $46 \%$, making it the seventh leading cause of death in the world. It is estimated that the prevalence will continue to increase and reach 592 million by 2035 (International Diabetes Federation, 2013). The prevalence of diabetes mellitus in Indonesia according to the Basic Health Research in 2007 is $5.7 \%$. DM prevalence was highest in West Kalimantan and North Maluku at $11.1 \%$, then Riau about 10.4\% (Health Research and Development Centre, Republic of Indonesia, 2007).

Type 2 diabetes mellitus (T2DM) characterized by the combination of genetic and non-genetic factors resulting from resistance to insulin action, inadequate insulin secretion, and inappropriate glucagon secretion. So far, the specific genes are complex and not clearly defined but are under investigation. Nongenetic factors include increasing age, central adiposity, overweight and high caloric intake, also sedentary lifestyle are comprise approximate 90 to $95 \%$ of cases in DM syndrome (Derek Le Roith et. al.,
2004). Diabetes frequently undiagnosed for several years because the hyperglycemia develops gradually and often not severe enough for patient to notice any of DM symptoms. However, such patients are at increased risk of developing macro and microvascular complications. Whereas patients with this form of diabetes may have level of insulin that appear normal or elevated, the higher level of blood glucose in these diabetic patients would be expected to result in even higher insulin values had their $\beta$-cell function been normal. Thus, insulin secretion is defective in these patients and insufficient to compensate for insulin resistance (American Diabetes Association, 2012; Derek Le Roith et. al., 2004).

The major treatments of type 2 diabetes mellitus so far are dietary, physical exercise, oral hypoglycaemic therapy, and insulin treatment, but the prevalence of mortality and morbidity much higher as well (Healthcare Improvement Scotland, 2010). Recent progress in DM therapy has focused attention on generation of surrogate $\beta$-cells from mesenchymal stem cells (MSCs) derived adult tissues (R.Y. Calne et. al., 2010). Autologous or allogeneic adult stem cell is the best alternative as source of stem cells to replace pancreatic cells because there is no rejection when transplanted.

MSCs are able to differentiate into various cell types, so that it is multipotent (Purwati et. al., 2013; Rantam et. al., 2014). But the properties of MSCs also influenced by the source of mesenchymal such as from 
bone marrow, adipose tissue, placenta, umbilical cord blood or amniotic membrane (Taran et. al., 2014). In this study, MSCs from adipose tissue will gradually grow and differentiate according to their environment. When MSCs inserted into the pancreas, it is expected it will differentiate into the pancreatic cells in order to be functioning as both exocrine and endocrine (Purwati et. al., 2013). Thus, transplanted MSCs from adipose tissue can repair the pancreas in its role as a paracrine effects and the effects of their own cell differentiation.

\section{Materials and Methods}

In this study, we conducted a phase I clinical trial in patients with T2DM through:

\section{Samples}

We used 40 patients with T2DM in various age between 30-79 years old (shown in Table 1), who were treated with autologous adipose-derived mesenchymal stem cells transplantation. MSCs injected into diabetic patients through catheterization. We measured levels of blood glucose, insulin, and cpeptide. Level of blood sugar was determined by measuring venous blood taken from the tail vein. Levels of glucose were measured at fasting and 2-hour after meals. Level of normal sugar in human was 70 to $120 \mathrm{mg} / \mathrm{dl}$. Determination of insulin and c-peptide levels were done using ELISA method. Eventually, the results between pre-injection and post-injection were compared.

\section{Mesenchymal Stem Cells Isolation and Culture from Adipose Tissue}

MSCs were derived from adipose tissue using aspiration and separation on Histopaque-1.077 (Sigma). Harvested cells were cultured in Dulbecco's Modified Eagles Medium containing $1.0 \mathrm{~g} / \mathrm{L}$ glucose. MSCs characterization were performed by analyzing the expression of $90+$, CD34- and CD105+ by using DAB immunostaining and FACS (BD).

Table 1. Frequency of DM patient's age

\begin{tabular}{|l|l|l|l|l|l|}
\hline Age & $30-39$ & $40-49$ & $50-59$ & $60-69$ & $70-79$ \\
\hline Frequency & 2 & 6 & 16 & 13 & 3 \\
\hline Mean & 56.675 & Std. Deviation & 10.40312 \\
\hline
\end{tabular}

Table 2. Levels of blood glucose, insulin, and c-peptide before and after injection

\begin{tabular}{|c|c|c|c|c|c|c|c|}
\hline & \multirow{2}{*}{$\begin{array}{l}\mathrm{HbA1c} \\
(\%)\end{array}$} & \multicolumn{4}{|c|}{ Levels of Glucose $(\mathrm{mg} / \mathrm{dl})$} & \multirow{2}{*}{$\begin{array}{l}\text { Level of } \\
\text { Insulin }(\mathrm{pg} / \mathrm{l})\end{array}$} & \multirow{2}{*}{$\begin{array}{l}\text { Level of C- } \\
\text { peptide (NG/1) }\end{array}$} \\
\hline & & BSN & $\mathrm{p}$ & $2 \mathrm{PP}$ & $\mathrm{p}$ & & \\
\hline $\begin{array}{l}\text { Pre- } \\
\text { injection }\end{array}$ & $\begin{array}{l}8.28 \pm \\
1.32\end{array}$ & $\begin{array}{l}148.78 \pm \\
48.17\end{array}$ & 0.000 & $\begin{array}{l}252.78 \pm \\
86.29\end{array}$ & 0.000 & $8.74 \pm 9.05$ & $2.44 \pm 1.65$ \\
\hline $\begin{array}{l}\text { Post- } \\
\text { injection }\end{array}$ & $\begin{array}{l}6.79 \pm \\
0.51 \\
\end{array}$ & $\begin{array}{l}102.33 \pm \\
10.36\end{array}$ & & $\begin{array}{l}129.16 \pm \\
9.61\end{array}$ & & $7.19 \pm 5.17$ & $2.98 \pm 1.05$ \\
\hline
\end{tabular}

\section{Results}

Three months after autologous adipose-derived MSCs transplantation, we measured the level of blood glucose including $\mathrm{HbA} 1 \mathrm{c}$, glucose levels at fasting and 2 hour post prandial, C-peptide and insulin.

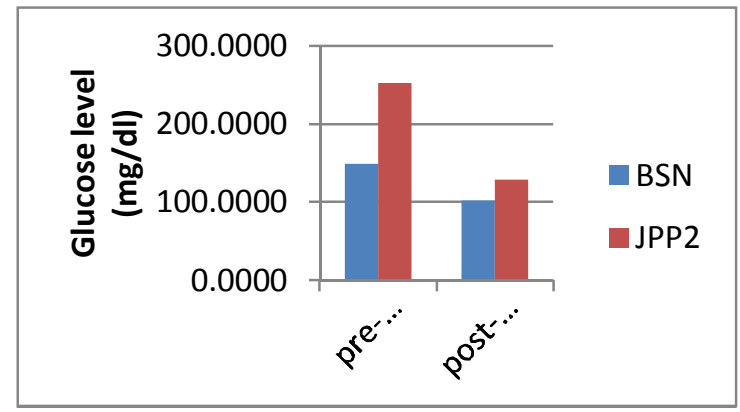

Figure 1. Blood glucose levels $(\mathrm{mg} / \mathrm{dl})$ at fasting and 2-hour postprandial before and after MSCs transplantation
Blood glucose levels at fasting and 2-hour postprandial plasma glucose were significantly decreasing after transplantation of MSCs as shown in Figure 1.

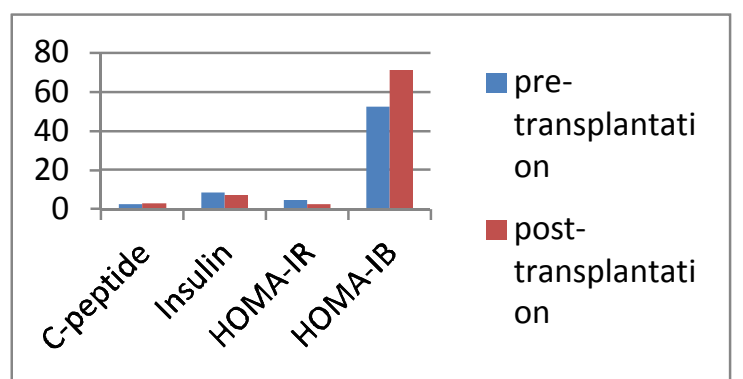

Figure 2. C-peptide, insulin, HOMA-IR and HOMAIB levels before and after MSCs transplantation 
We measured c-peptide and insulin levels before and after autologus MSCs transplantation and the results shown in Figure 2. C-peptide level was increasing after transplantation of MSCs, and insulin was significantly decreasing after transplantation of MSCs. HbAlc also decreasing when measured at three months after transplantation of MSCs as shown in table 2 .

\section{Discussions}

Diabetes mellitus (DM) which is characterized by hyperglycemia is a group of metabolic diseases associated with dysfunction, failure of different organs, and long-term damage resulting from defects in insulin action, insulin secretion, or both (American Diabetes Association, 2012). Insulin is hormone that consists a series of amino acids produced by the $\beta$ cells of pancreas gland. Insulin is an important function in the body to regulate glucose and in glucose utilization in almost all body tissues, especially muscle, fat and liver. When obtained either disruption or utilization of insulin secretion that cause diabetes, which recognized the DM type 1 and 2 (De Fronzo R.A et. al., 2004).

Mesenchymal stem cells are precursors of nonhematopoietic tissues that are relatively easily obtained. These cells are easy to store at subzero degrees, suggesting a relatively low immunogenicity, and the most important is it remains multipotent after in-vitro expansion. Mesenchymal stem cells are hypoimmunogenic and can escape from host immune elimination (Purwati et. al., 2013).

In this study, we showed that injection of adipose-derived autologous mesenchymal stem cells can at least in section, reconstitute the insulin production in patients with T2DM. Prior to use, MSCs suspensions were first validated for its purity level and measured using CD105+ and CD34- expression. This indicated that the cells were indeed mature MSCs (Dominici M et. al., 2006).

According to this study, levels of blood glucose at fasting and 2-hour postprandial and insulin in patients were significantly decreasing after MSCs transplantation. HbAlc also decreasing when measured at three months after transplantation from $8,28 \%$ to $6,79 \%$. HbAlc is a blood test that is important to see how well the treatment of diabetes. It means the tests will illustrate the average blood sugar over the past 2 to 3 months and is used in conjunction with regular blood sugar checks to make adjustments in the control of diabetes.

\section{Conclusion}

In conlusion, it is provide that adipose-derived mesenchymal stem cells for treatment tertiary failure diabetes mellitus type 2 was better than insulin treatment only.

\section{Corresponding Author:}

Dr. dr. Purwati, Sp.PD, FINASIM

Stem Cell Research and Development Centre

Institute of Tropical Disease, Universitas Airlangga

Surabaya 60115, Indonesia

Telephone: +6281332075261

Email: purwatipanpan@yahoo.com

\section{References}

1. American Diabetes Association. 2012. Diagnosis and Classification of Diabetes Melitus. Diabetic Care. 35 suppl: 568.

2. De Fronzo RA, Ferrannini E, Keen H, Zimmet P. 2004. International Textbook of Diabetes Mellitus, 3rd Edition. Chichester, UK: John Wiley and Sons.

3. Derek Le Roith, Simeon I. Taylor, Jerrold M. Olefsky. 2004. Diabetes Mellitus: A Fundamental and Clinical Text. Philadelphia: Lippincott William \& Wilkins. pp. 458-460.

4. Diabetes Control and Complications Trial Research Group. 1993. The Effect of Intensive Diabetes Treatment on The Development Progression of Long-Term Complications in Insulin-Dependent Diabetes Mellitus: The Diabetes Controland Complication Trial. N Engl J Med; 329:978-986.

5. Dominici M, Le Blanc K, Mueller I, SlaperCortenbach I, Marini F, Krause D, Deans R, Keating A, Prockop D, Horwitz E. 2006. Minimal Criteria for Defining Multipotent Mesenchymal Stromal Cells. The International Society for Cellular Therapy Position Statement. Cytotherapy, 8: 315-317.

6. Healthcare Improvement Scotland. 2010. Management of Diabetes: A National Clinical Guideline. Scottish Intercollegiate Guidelines Network. pp. 39-54.

7. Health Research and Development Centre, Ministry of Health Republic of Indonesia. Basic Health Research Reports. 2007.

8. International Diabetes Federation. 2013. IDF Atlas Sixth Edition.

9. Purnamasari D. Diagnosis dan Klasifikasi Diabetes Melitus. Dalam: Sudoyo A, Setiyohadi B, Alwi I, Simadibrata M, Setiati S. Buku Ajar Ilmu Penyakit Dalam Jilid 3. 5th Edition. Jakarta: 
Interna Publishing. p. 1880-3.

10. Purwati, Fedik. A.R, Sony W, Anas P, Eric H, Helen S, Deya K. 2013. Autologous MSC Bone Marrow Stem Cell and Allogenic Pancreatic Stem Cell for Repair of Beta Pancreatic Cell in Experimental Diabetes Mellitus. African Journal of Internal Medicine Vol. 1 (1), pp. 010-016 (C) International Scholars Journals.

11. R.Y. Calne, S.U. Gan, K.O. Lee. 2010. Stem Cell and Gene Therapies for Diabetes Mellitus, Nat.
Rev. Endocrinol. 6 173-177.

12. Rantam et. al. 2014. Induced Monocytes Derived HSCs (CD34+) with LPS Accelerated Homing Rat-Bone Marrow Mesenchymal (CD105) in Injured Pancreas. International Seminar Cleaveland, OHIO USA.

13. Taran et al. 2014. Invitro and Invivo Neurogenic Potensial of Mesenchymal Stem Cell Isolated from Different Sources. Bioscience Journal. 